Makwembere, S. Disability Sensitivity and Sensibility: A Nondisabled Lecturer Perspective on Inclusive Lecturing Opportunities

\title{
Disability Sensitivity and Sensibility: A Nondisabled Lecturer Perspective on Inclusive Lecturing Opportunities
}

\author{
Sandra Makwembere \\ Walter Sisulu University, Department of People Development and Technology, South Africa \\ E-mail: smakwembere@wsu.ac.za \\ Received : 2021-06-16 \\ Revised : 2021-07-27 \\ Accepted : 2021-08-18 \\ do \\ $10.46303 /$ ressat.2021.11
}

\begin{abstract}
How to cite this paper: Makwembere, S. (2021) Disability Sensitivity and Sensibility: A Nondisabled Lecturer Perspective on Inclusive Lecturing Opportunities. Research in Social Sciences and Technology, 6(2), 52-75. https://doi.org/10.46303/ressat.2021.11

This is an Open Access article distributed under the terms of the Creative Commons Attribution 4.0 International license (https://creativecommons.org/licenses/by/4.0/).
\end{abstract}

\begin{abstract}
Disability is a social force that arguably creates more education problems for students with disabilities than their impairments. Understanding it as a form of social oppression can lead to less exclusionary teaching and learning attitudes, beliefs, expectations and practices. Numerous studies have looked at the experiences of staff and students with disabilities as well as the experiences of teaching students with disabilities. However, more studies are needed to better understand and address disability in higher education. Nondisabled perspectives have a role to play in opposing disabling educational practices and cultures to make higher education more inclusive. Many opportunities especially exist for nondisabled lecturers to contribute to addressing the higher education barriers and discrimination which often affect students with disabilities. The purpose of this study was to use a disability perspective to present my lecturing practices during the move to emergency remote teaching and learning in response to COVID19 while working at an HDI. An autoethnographic method was used. Content analysis of my accounts exposed the exclusionary nature of my practices in terms of how they facilitated ableism and suppressed disability discourse. Recommendations are made, in light of the results, on ways to not only make higher education spaces more accommodating but counter a wider societal culture that oppresses and even seeks to eradicate the value of those who live with impairments.
\end{abstract}

Keywords: ableism; disability; education access; higher education; inclusive higher education 
Makwembere, S. Disability Sensitivity and Sensibility: A Nondisabled Lecturer Perspective on Inclusive Lecturing Opportunities

\section{Introduction}

Social, physical, institutional and attitudinal environments appear to still be failing to meet the needs of people with disabilities and, in higher education institutions (HEls), more needs to be done to understand why this is the case (Broido, 2020; Howell, 2018; Mutanga, 2017; Snounu, 2019; Zongozzi et al., 2019;). HEls continue to suffer from practices which marginalise and exclude students with disabilities (Dolmage, 2017; Timberlake, 2020). According to the United Nations Convention on the Rights of Persons with Disabilities (UNCRPD), disability results "from the interaction between persons with impairments and attitudinal and environmental barriers that hinder their full and effective participation in society on an equal basis with others" (UNCRPD, 2006). Different models can be used to explain disability and the social and human rights models are adopted here. According to the social model of disability (SMD), disability can be understood as i) a social construct not a consequence of impairment, ii) a consequence of complex interrelationships between impairment, individual responses to impairment and the social environment and iii) the cause of social disadvantage experienced by people with disabilities (Hosking, 2008). The main proposition by social model theorists is that "it is the social and political aspects of disability, not the bodily aspects, which afford the profound levels of disadvantage under which disabled people struggle" (Swartz \& Watermeyer, 2006, p. 2). In essence, disability is a "form of social oppression" (Thomas, 1999). From this perspective, lecturing practices that exclude students with disabilities would be oppressive. The human rights model of disability takes disability as a human rights issue. Disability is understood as part of human diversity and not a basis to deny or limit any person's rights (Degener, 2014). The position largely stems from the rights of people with disabilities contained in the UNCRPD. From this viewpoint, exclusionary lecturing practices would be a human rights issue because of the associated denial or limitation of the rights of students with disabilities.

Disability is an issue of power (Rocco, 2005). Disablist environments make people with disabilities invisible or discounted (Rocco, 2005; Hirschmann, 2014). In public domains, people with disabilities are misrepresented or unrepresented at all (Swartz et al., 2018). This "exclusion from the social and representational order is a forceful form of symbolic violence" (Swartz et al., 2018, p. 21). This negative social value can become internalised and constitute a form of symbolic violence experienced by people with disabilities (Swartz et al., 2018). Furthermore, "when exclusion is the norm, it is bound to produce ideological justifications for the systemic problems produced by it" (D'Souza, 2020, p. 1177).

In South Africa, despite the introduction of a higher education disability policy in 2018 and other legislative and policy provisions for disability equity, disability is an issue not well addressed in many universities. For historically disadvantaged institutions (HDIs) which already suffer many challenges, such as a lack of infrastructure as well as human and financial resources, prioritising ways to tackle disabling environments can facilitate inclusivity. HDIs refer to a category of universities that catered for Black people under apartheid and are presently classified as such to redress historic inequalities (Africa \& Mutizwa-Mangiza, 2018). Seven universities are presently classified as HDIs: the University of Fort Hare, the University of Limpopo, the University of Venda, Walter Sisulu University, the University of the Western Cape, the University of Zululand and Mangosuthu University of Technology. The Sefako Makgatho Health Science University, a former campus of the University of Limpopo, is also classified as an HDI. 
Makwembere, S. Disability Sensitivity and Sensibility: A Nondisabled Lecturer Perspective on Inclusive Lecturing Opportunities

These institutions have a history of being marginalised and have many students from disadvantaged backgrounds (Africa \& Mutizwa-Mangiza, 2018). Relating to disability, not enough attention has been paid to lecturing experiences during the COVID-19 pandemic at these institutions.

Literature is replete with experiences of students with impairments being disabled by their university environments (Moswela \& Mukhopadhyay, 2018; Ngubane-Mokiwa \& Zongozzi, 2021; Zongozzi, 2020) as well as lecturer experiences of teaching students with varying impairments (Mutanga \& Walker, 2017; Svendby, 2020). However, there is limited literature on the reflections of the lecturers who might be creating disabling situations and their perspectives on how they facilitate disabling experiences. In a study on the forms of support offered to students with disabilities by the Disability Unit at the University of Venda, an HDI, Mbuvha (2019) found that students did not get sufficient additional support from lecturers such as tutorials, curriculum differentiation and extra learning materials adapted for their needs. The study highlighted lecturer behaviours that hinder inclusivity. However, the lecturers' views on those students' experiences were excluded. Lecturers are important role players in creating more or less inclusive environments; thus, some attention should be paid to how they do this. Concerning nondisabled lecturers in particular, investigations that include their individual reflections can help to identify the "deeply conditioned" (Watermeyer, 2006, p. 35) assumptions 'within' that lead to teaching and learning practices that are consciously, unconsciously or dysconsciously exclusionary.

The purpose of the study was to use a disability perspective to present my lecturing practices during the move to emergency remote teaching and learning (ERTL) in response to COVID-19 while working at an HDI.

\section{Research Question}

The research question was:

In what ways did I lecture, from a disability perspective, in terms of what I perceived and assumed was expected of me and my delivery of course materials, during the move to ERTL in response to COVID-19?

What follows is a review of literature on disability in higher education and inclusive lecturing. Then, the social and human rights models of disability are presented. The methodology is outlined, followed by a presentation of the results according to the themes of ableist conditioned barrier building and reinforcing disability silences. The results are discussed and finally, the conclusion and recommendations are presented.

\section{Literature review}

\section{Disability in South African higher education}

Article 24 of the UNCRPD (2006) states that, persons with disabilities should be assured of the right to inclusive education at all levels. South Africa, as a signatory of the UNCRPD, has to demonstrate its commitment to address disability. Croft (2010) observed that people with disabilities are excluded from educational opportunities and face difficulties in progressing to tertiary levels. Moreover, education models still battle to accommodate the broad needs of 
Makwembere, S. Disability Sensitivity and Sensibility: A Nondisabled Lecturer Perspective on Inclusive Lecturing Opportunities

people with disabilities and political dialogue on the disability in higher education is yet to reach prolific levels. A core problem has been the "invisibility" of people with disabilities in systems of freedom (Quinn \& Degener, 2002). What seems to be apparent is that people with disabilities are excluded from political influence and are perceived to be too few to deserve resource investment, hence, significant higher education policy and research 'silences' on disability are witnessed (Morley, 2011; Verstraete, 2017).

Despite seemingly progressive policy, for example, the National Education Policy Act 27 of 1996, the Draft Policy for the provision of quality education and support for children with severe to profound intellectual disabilities (2016) and the Strategic Policy Framework on Disability for the Post-School Education and Training System (2018), much still needs to be done to implement and sustain initiatives that support and include students with disabilities. It is well recognised that many universities are not fully equipped to cater for disabilities (Morley \& Croft, 2011; Pudaruth, Gunputh \& Singh, 2017; Southern Africa Federation of the Disabled, 2018). As Morley and Croft (2011, p. 393) noted, "while awareness about exclusion and equalities is developing, disability is a structure of inequality that has received little policy or research attention in higher education in low-income countries".

Studies on disability in South African universities have raised several issues. In a mixed method study on staff and students with disabilities' experiences of disability support, inclusion and exclusion at Stellenbosch University, Lyner-Cleophas (2016) found that there were inclusive and exclusive practices at that university. The policy was inclusive, however, practices such as inconsistent lecturer support, inadequate training to deal with disability and less attention to less visible disabilities, resulted in exclusions. Mutanga's (2018) qualitative study on the academic and life experiences of students with disabilities at two HDIs (the University of Fort Hare and University of Venda) revealed that their policies needed to be more inclusive. Mutanga (2018) found that students with disabilities struggled to access teaching and learning because of issues such as little effort made by lecturers to offer alternative consultation times, an inability to access study materials in friendly formats, a shortage of resources such as braille books as well as inaccessible teaching and learning methods used by lecturers. In a qualitative study of e-learning needs of students with disabilities at a South African university, Jaarsveldt and Ndeya-Ndereya (2015) found that lecturers distanced themselves from giving support to students with disabilities. This was attributed to their lack of knowledge and skills relating to disability, their lack of anticipation of disability needs as well as psychological factors such as discomfort and uncertainty. They argued that lecturers should accept responsibility for understanding accessibility issues and establish inclusive learning environments (Jaarsveldt \& Ndeya-Ndereya, 2015). Additionally, that "through raising the confidence levels of lecturers and encouraging them to engage in a continuous process of self-reflective practice - there will be steady progress towards inclusive education" (Jaarsveldt \& Ndeya-Ndereya, 2015, p. 210). In a study on lecturer perspectives on the academic lives of students with disabilities, Mutanga and Walker (2017) uncovered that lecturers blamed students with disabilities or the institution for their challenges, lacked an understanding of diversity and treated students with disabilities as a homogenous category. Furthermore, the lecturers acknowledged "their lack of awareness on how to react and act when confronted by students with disabilities or disability issues in 
Makwembere, S. Disability Sensitivity and Sensibility: A Nondisabled Lecturer Perspective on Inclusive Lecturing Opportunities

practice" (Mutanga \& Walker, 2017, p. 5). Similar to Jaarsveldt and Ndeya-Ndereya (2015), Mutanga and Walker (2017, p. 7) made pertinent observations that:

Lecturers need to be aware and be reflective of their perspectives and behaviour. Selfreflection, which involves deep inward looking into every action is critical for lecturers to become more aware and active in meeting the needs of all students. This is only possible if lecturers are willing to self-examine their own conceptions.

This article is a response to Mutanga and Walker's (2017) call.

\section{Inclusive lecturing}

Inclusive lecturing "is about responding to the spectrum of different needs that any crowd of human beings will present to [lecturers]. Some of these are visible...others are not. Some of the needs are well known to their owners, others are not" (Brown \& Race, 2003, p. 164). It caters for the needs of students with various impairments (Amka, 2017). Determining how to enhance access to higher education as well as the best ways to include underrepresented groups, in particular people with disabilities, is a challenging task for many lecturers (Ukpabio, 2019; Chiwandire, 2019; Nurjannah, Rahajeng \& Arawindha, 2021). Using inclusive lecturing strategies can address accessibility challenges. When lecturing is not inclusive, it reinforces barriers to education experienced by students with disabilities (Osborne, 2019; Munemo \& Bekele, 2020; Hsu et al., 2020) and ableism (Dolmage, 2017; D'Souza, 2020). Ableism is a predominately "unconscious acceptance of able-bodied privilege and sense of normal that does not need to be defined; normal is recognisable and "we know it when we see it" (Timberlake, 2020, p. 85). It can also be dysconsicious (Broderick \& Lalvani, 2017), meaning it is "a flawed awareness- a way of thinking about disability that upholds and is upheld by, mainstream ideology around normality" (Timberlake, 2020, p. 91). It renders disability as "abject, invisible, disposable, less than human" (Dolmage, 2017, p. 7). The exclusion of people with disabilities is an inherent feature of ableism. The risk of taking such exclusion for granted is that "students with disabilities... will be seen as inevitable victims of an immutable part of social life and consequently treated as preordained failures" (D'Souza, 2020, p. 1181) and be marginalised. Concerted efforts are necessary to "eliminate or minimise the barriers that limit the correct learning of...students" (Rueda \& Cerero, 2019, p. 98) created by ableism.

Universal Design for Learning (UDL) is an educational approach to teaching, learning and assessment that can be applied to respond effectively to student differences (Wilson, 2017). It is a framework that can reduce barriers of accessing course activities and content when it is applied (McGeehan, 2020). It gives guidance on how to provide multiple means of engagement, representation and means of action (Chiwandire, 2019). For example, the use of pause procedure, where short breaks are taken to review notes or discuss topics covered, can improve the accuracy of notes as well sustain student attention. This is valuable for students with learning disabilities (Pedroza, 2019). UDL encourages the use of different teaching approaches and forms of assessment to reduce giving privilege to one type of student. When it comes to the use of multiple methods, it emphasises the range of formats used per method in addition to the number of methods. When it is applied well, UDL can lead to learning environments that are more inclusive of all students, not simply for students with disabilities (Chiwandire, 2019; McGeehan, 2020). 
Makwembere, S. Disability Sensitivity and Sensibility: A Nondisabled Lecturer Perspective on Inclusive Lecturing Opportunities

Despite institutional goals that might be set to advance inclusive lecturing and incorporate UDL principles in teaching and learning, many educational practices still largely benefit students without disabilities and this seems to even be perceived as 'normal' (Kilinc, 2021). Further research into lecturing experiences is needed to provide insights into how they demonstrate exclusionary educational practices and how these can be shaped to be more inclusive of the needs of students with various impairments (Amka, 2017).

\section{Social and human rights models of disability}

The social model of disability (SMD) and human rights model of disability (HRMD) are two complementary models of disability (Lawson \& Beckett, 2020) which are useful for positioning one's understanding of disability and subsequently, how one might facilitate it. SMD focuses on the barriers (attitudinal, physical, political and so on) that exist separately from an individual's impairment. The main premise is that society disables individuals and groups by catering for the needs of people who do not have impairments. The model emerged in the United Kingdom in the 1960s and the use of the actual term 'social model of disability' is traced to the 1980s. Oliver (1983) coined the phrase and is credited as a pioneer of the model. Oliver (1996) stated that:

It is society which disables physically impaired people. Disability is something imposed on top of our impairments by the way we are unnecessarily isolated and excluded from full participation in society. Disabled people are therefore an oppressed group in society...it is necessary to grasp the distinction between the physical impairment and the social situation called 'disability' of people with such impairment...impairment [is] lacking all or part of a limb or having a defective limb, organism or mechanism of the body and disability [is] the disadvantage or restriction of activity caused by a contemporary social organisation which takes little or no account of people who have physical impairments and thus excludes them from participation in the mainstream of social activities. (Oliver, 1996, p. 22)

The model rests on these arguments. Impairment is distinguished from disability where impairment pertains to a condition of the mind or body and disability results from the way society responds to that impairment (Degener, 2014). Oliver (2004, p. 30) argued that the model is "a practical tool, not a theory, an idea or a concept". Disabling situations are partially created by people's choices (Samaha, 2007). In a university context, for example, a lecturer's choice of slides purely for personal aesthetic pleasure could be exclusionary and disabling. Working based on preferences overlooks the universal appropriateness of materials to accommodate students with various visual needs including students with visual impairments. 
Makwembere, S. Disability Sensitivity and Sensibility: A Nondisabled Lecturer Perspective on Inclusive Lecturing Opportunities

Figure 1. Social Model of Disability (Adapted from Samaha, 2007)

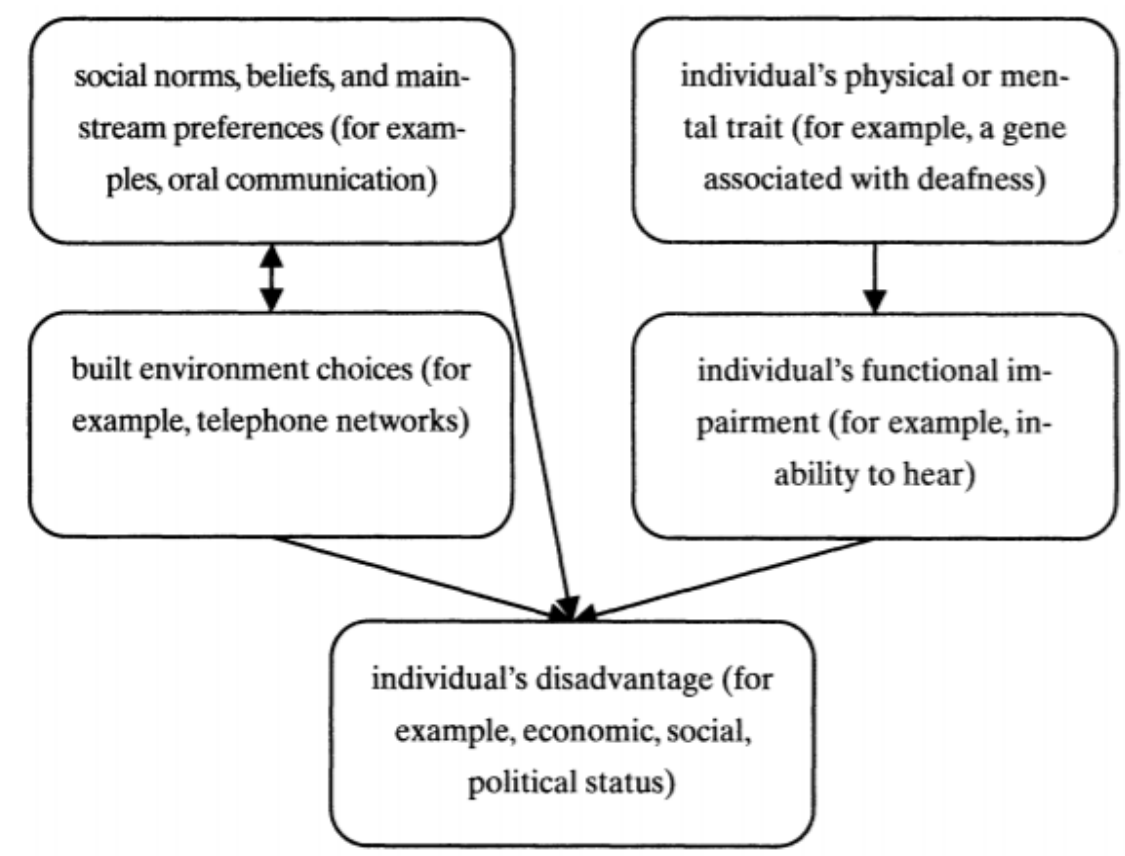

Concerning remedies to disability, the model places the responsibility on society, not the person with an impairment, to remove the disabling barriers. The exclusions and oppression of people with impairments are to be resisted in all social arrangements of society.

The human rights model of disability (HRMD) concentrates on the inherent dignity of human beings and afterwards, but only if necessary, on a person's medical characteristics. It places the individual at the centre of all decisions affecting him/her and, most importantly, situates the main 'problem' outside the person and in society (Degener, 2014; Quinn \& Degener, 2002). Similar to the SMD, societal factors account for disability. Every person, by virtue of being human, is a human rights subject and the human rights they are entitled to do not need the absence of impairment. The human rights encompass civil and political as well as economic, social and cultural rights. These two sets of rights are indivisible and interdependent (Degener, 2014). Furthermore, the HRMD strives for social justice by offering a "roadmap for change" (Degener, 2014, p. 26). The UNCRPD human rights treaty has especially shaped policy responses to disability by providing a rights framework within which policy can be developed. Consequently, disability is being mainstreamed into policy areas where it was previously not considered thereby enhancing social justice. Concerning university contexts, this model positions these spaces as places where the rights of students with disabilities must be realised. Therefore, lecturers have a duty to ensure the rights of students with disabilities are respected.

While some view the HRMD as a departure from the social model; others view it as an expansion and improvement of the SMD. Lawson and Beckett (2020, p. 350) argue that "the relationship between the two models is one in which neither can be viewed as an improvement on the other because each has distinctive roles to play". The two theories can be applied in a complementary way to understand disability in higher education contexts. 
Makwembere, S. Disability Sensitivity and Sensibility: A Nondisabled Lecturer Perspective on Inclusive Lecturing Opportunities

\section{Methodology}

\section{Design}

A qualitative design was chosen. Specifically, retrospective autoethnography was used. It enabled an identification and questioning of the junctions between 'self and society', 'the particular and the general', 'the personal and the political', demonstrating myself "in the process of figuring out what to do, how to live and the meaning of [my] struggles" (Adams et al., 2015, p. 1-2). It is valuable for educational research (Starr, 2010) and was chosen because it "can produce personally, professionally and socially useful understandings of teaching and researching in higher education" (Pillay, Naicker \& Pithouse-Morgan, 2016, p. 14).

\section{Data and Sources of Data}

The primary data were my lecture slides, my lecture recordings, WhatsApp messages and typed up and handwritten notes (self-data), of what could be recalled of main events and steps taken. The focus was on three courses that I lectured under ERTL while working for a South African HDI in 2020. The courses were Business Management, Labour Law and Research Methodology. The Business Management course had 130 students, the Labour Law course had 91 students and Research Methodology course had 53 students. The main data collection process of collating materials took place over a week (5-11 April 2021). For the first part of the week, I looked over course lectures slides, listened to lecture videos while taking notes of my perceptions and assumptions. The written record allowed me to capture personal matters (Fiske, 1990). The process was hampered by a failure to recall precise events (Wamsted, 2012) and disruptions to the times dedicated to recalling events but the recollections intended to focus on "lifting out and sharing meaning from (marginalised) experiences" (Schmid, 2019, p. 273).

\section{Data Analysis}

Written, typed up data, were manually analysed through qualitative content analysis. The unit of analysis was my lecturing material. The analysis of texts involved coding texts then extracting themes (Mayring, 2000). A process of coding led to an identification of themes which do not "generate concepts and theory, but instead...describe the meanings and actions of [myself] and texts" (Drisko \& Maschi, 2016, p. 105). A selection of audio and video data was used to augment text data. The videos were not transcribed, instead reflections on what was watched or listened to formed part of analysis.

\section{Results}

Two main themes emerged from categorising my lecturing experiences and reflections. These are presented next.

\section{Ableist conditioned barrier building}

Ableism was revealed in the perceptions and assumptions of what was expected of me, in the delivery of course materials. Although no student in any of the courses disclosed that they had a disability, not catering for students with disabilities was presented as a conditioned rather than planned behaviour and created barriers to potential learning from a disability perspective. 
Makwembere, S. Disability Sensitivity and Sensibility: A Nondisabled Lecturer Perspective on Inclusive Lecturing Opportunities

\section{Perceptions and assumptions about what was expected}

When the first lockdown was announced on the $23^{\text {rd }}$ of March 2020, I was unsure about what to expect. I wondered how I would work under the circumstances. The notion of social distancing was new and I wondered how it was meant to be managed. From April 2020, I attended several meetings at departmental, faculty and institutional levels where the responses to COVID-19 were discussed and resolutions were made. At all the meetings I attended, disability was incomprehensively discussed. By June 2020, I began some interactions with students via WhatsApp.

Below is a personal narrative I wrote which summarises what I did:

After the beginning of national lockdown was announced on 23 March 2020, for the first time, I could not physically go to work freely for reasons unrelated to institutionally based disruptions. Initially, I thought the situation would not be for long, so was not very concerned. At the time, I did not realise the implications of lockdown nor did I anticipate how quickly the institution would decide in response to the situation. Several new policies were introduced to support ERTL. I had to decide how I was going to manage teaching and learning activities under the circumstances. Between April and May 2020, I participated in different pieces of training such as how to use the university learning management system and Microsoft Teams...I also did my research on other online platforms such as Google and Zoom and on how to instruct and assess online. Despite the time invested, still, I did not feel I was fully knowledgeable and equipped to enter ERTL. I knew that there was no option but was not confident that the preparatory process I had gone through was enough. I placed the course materials (slides and course outlines) on the university learning management system....when June 2020 arrived, I began some contact with students via WhatsApp groups. WhatsApp became the main medium of communicating with students. I did not receive as many messages as I had feared when I created the groups. From July 2020, I had more interactions with students on WhatsApp as well as the university learning management system. I sent prerecorded lecture videos on the WhatsApp groups as well as posted these on the learning management system. I had a few live online classes on Blackboard and MS Teams where I displayed slides and at times showed videos from YouTube. Of the courses I lectured, the main challenges students faced was network connectivity and data access problems. I accommodated these challenges by having shorter live classes, sending prerecorded videos instead of having live classes and changing assessment dates (S. Makwembere, personal communication, April 5, 2021).

The decisions about how I was going to manage teaching and learning activities were based on my perception that all the students I needed to cater for had the same learning needs. I prepared myself to along these lines. I researched on how to use different platforms, instruct and assess online assuming that I would cater for uniform student needs. I placed materials on the learning management system in single formats (Microsoft Document, Powerpoint or Portable Document Format). These were formats that I was familiar with and felt comfortable to use. I believed that the formats were sufficient. When I contacted students on WhatsApp, I assumed that they had no challenges in receiving my messages other than network connectivity 
Makwembere, S. Disability Sensitivity and Sensibility: A Nondisabled Lecturer Perspective on Inclusive Lecturing Opportunities

or data access. I believed that once I sent a message, it was received as it was sent. When it came to the prerecorded videos, I spoke as I went through slides believing that what I said would be heard and the images I presented would be seen. During live online classes on Blackboard or Microsoft Teams, which tended to be one hour to one and a half hours long, I was the main person who spoke. I held my lectures without video and believed that this method was sufficient as I assumed that all the students who attended only needed to hear me. I usually gave students an opportunity to ask questions after I was done but rarely received any questions. I thought that this meant that the students had no requests or that if they had any needs, that they would find a way to have these resolved by themselves. The accommodations I made to my lecturing were mainly to accommodate student network connectivity or data issues. In my view, these were the main needs students had expressed thus most accommodations were in response to this.

\section{Course material delivery}

Lecture slides and lecture videos were placed on the online learning management system Blackboard and were sometimes distributed via WhatsApp. I prepared lecture slides for classes using Microsoft Office and pre-recorded videos using Screencast-o-matic. Materials were viewable on Blackboard as illustrated in Figures 2 and 3. Lecture slides were uploaded in Microsoft PowerPoint format and lecture videos were in MP4 file format.

Figure 2. Lecture slides posted on Blackboard
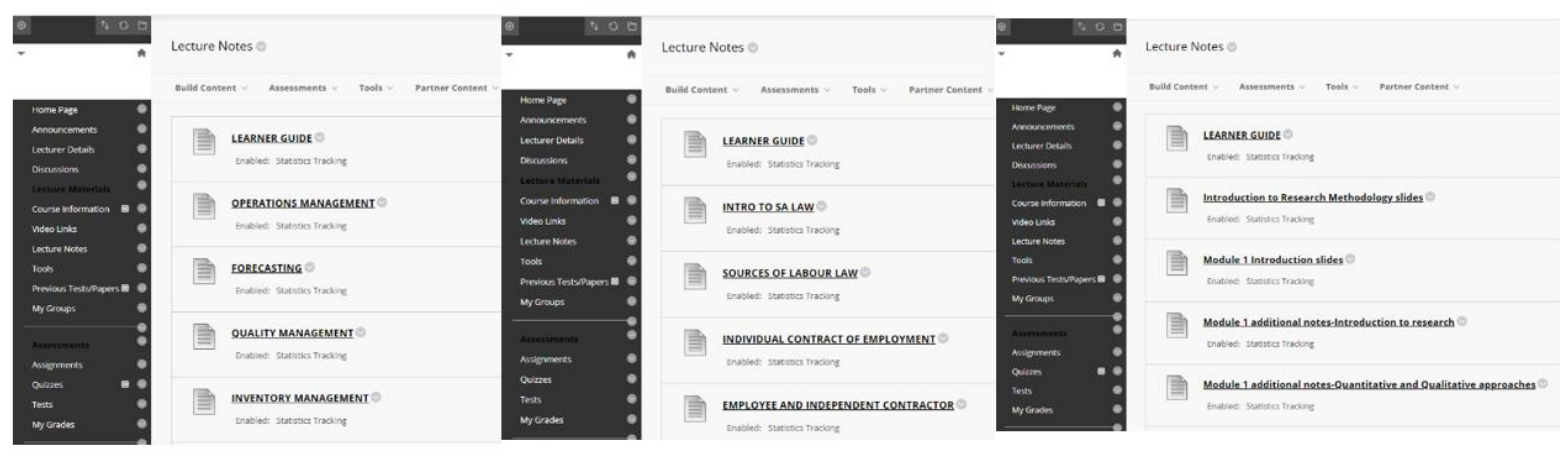

Figure 3. Videos posted on Blackboard
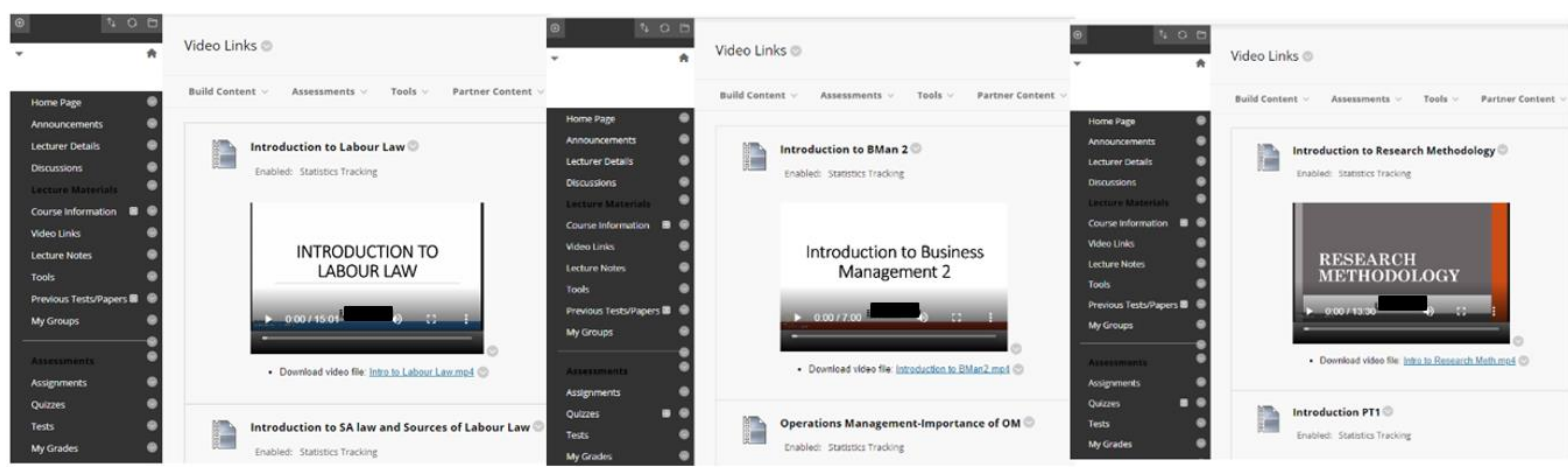
Makwembere, S. Disability Sensitivity and Sensibility: A Nondisabled Lecturer Perspective on Inclusive Lecturing Opportunities

The slides and videos were uploaded during the year and left on the platform for students to access.

I recounted the following in my notes concerning my use of Blackboard:

I put everything on Blackboard. No one told me about any particular features that I could use for students with disabilities. I don't think I would necessarily have needed to use them but it would have been nice to know I had the options. I'm disappointed that I didn't ask...it's rather late now, it's done...I think it might've been a lot of effort...The way I prepared was as I had done previously, there didn't seem to be a need to do anything differently (S. Makwembere, personal communication, April 5, 2021)

The lecture slides typically included English written text and different images or figures. Figures 4 to 7 illustrate my typical presentation of slides. At times, the slides had links to YouTube videos as shown in Figures 4 and 5. During classes, the YouTube videos would be shown to students. If a pre-recorded lecture was prepared, the YouTube video would be shown as part of the recording too.

Figure 4. Business Management lecture slides with links to YouTube videos

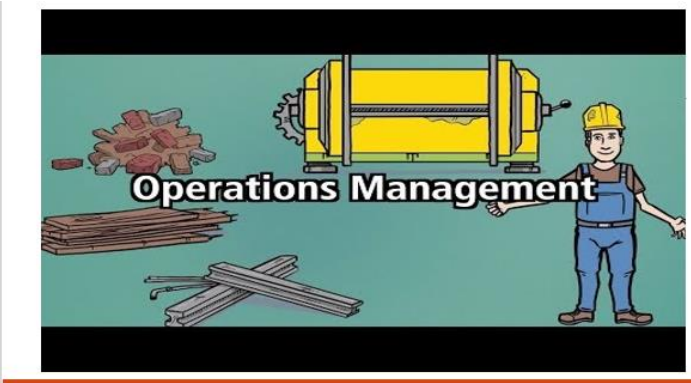

3

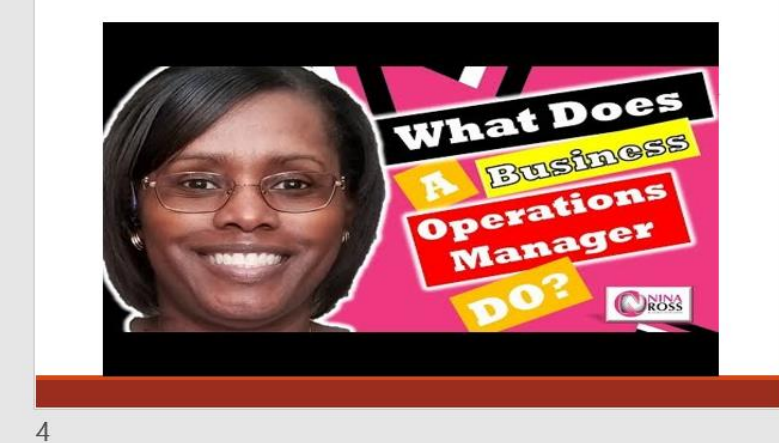

OPERATIONS MANAGEMENT

\section{Some terms used in OM}

Operations function $=$ The function primarily aimed at the utilisation of resources to manufacture products or render services.

Operations managers $=$ Personnel in the business directly responsible for managing the operations function.

- Operations management $=$ Involves operations manager's activities, decisions and responsibilities that tie in with the execution of the operations function. 
Figure 5. Research Methodology lecture slides with links to YouTube videos

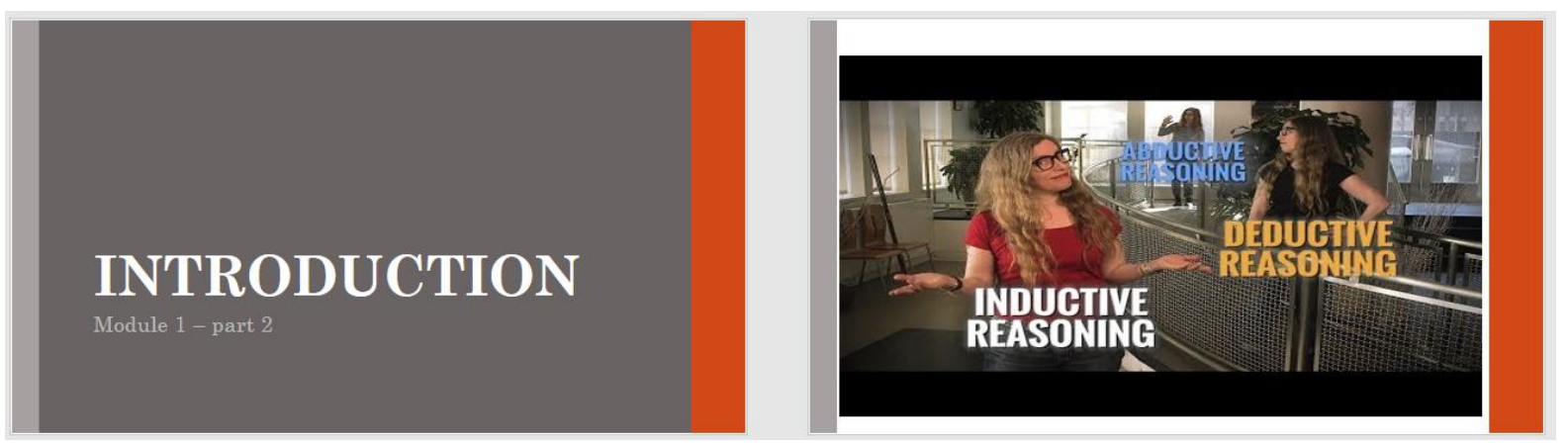

I recalled my incorporation of videos as follows:

I liked the option to show videos. I didn't get to do that last year. I never showed any videos in classes, it was just impossible...It seemed too much effort to rearrange class schedules and go through the venue booking system...I was now able to get around this. I feel proud that I tried this out. I'm not sure if these were the best possible videoes but they were nice in my view...I heard about captions and alternative text earliler this year on Twitter. I never thought to use these options at all. If there was any person in class that needed them, they must've been so annoyed...felt cheated. (S. Makwembere, personal communication, April 5, 2021)

At times, images were included in the lecture slides such as in Figures 6 and 7. Sometimes animations were also used with the images to emphasise certain points as illustrated in Figure 6.

Figure 6. Business Management lecture slides with images
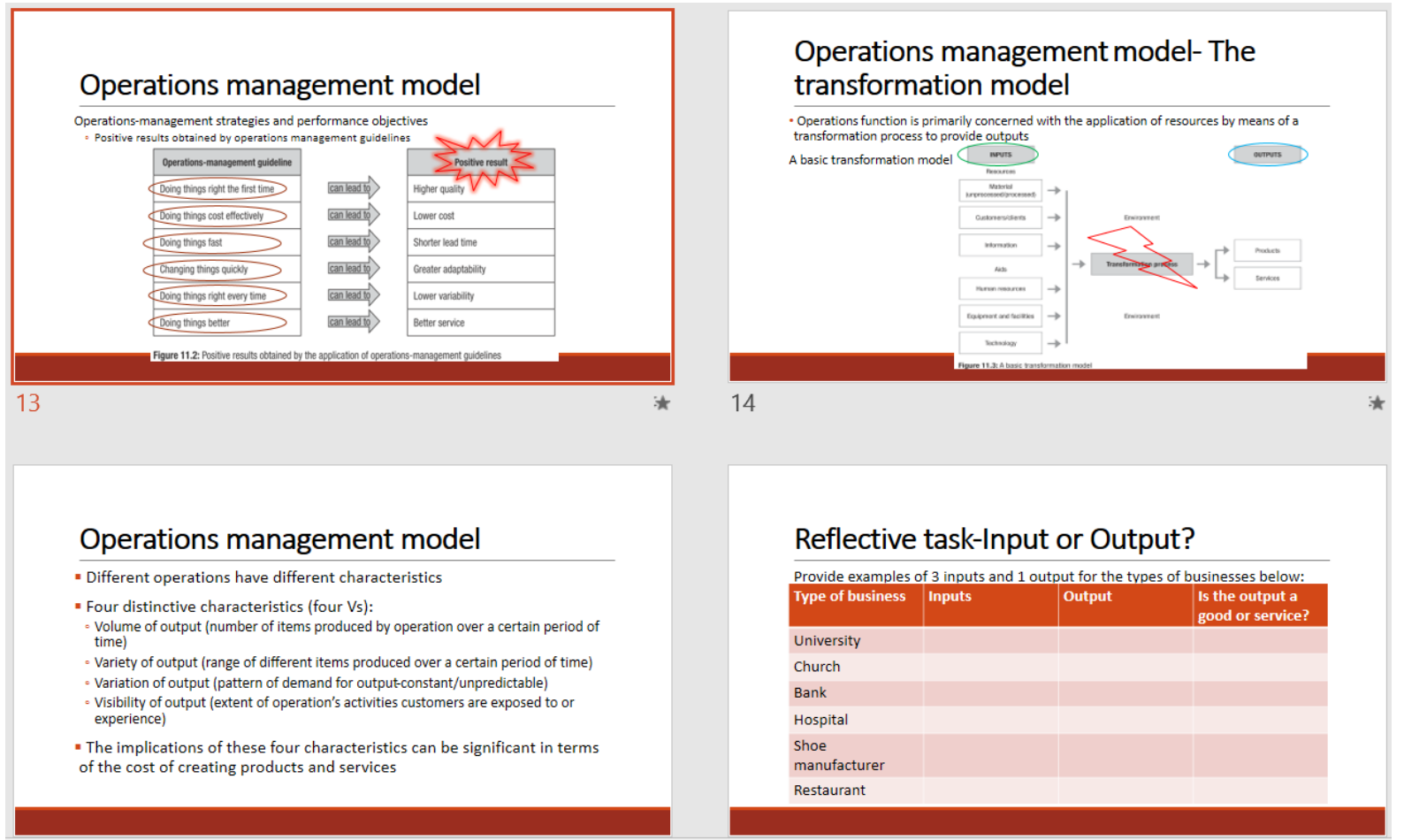
Makwembere, S. Disability Sensitivity and Sensibility: A Nondisabled Lecturer Perspective on Inclusive Lecturing Opportunities

Concerning the additional features I included on slides, my thoughts were as follows:

I like animations. I don't use them much but here (Slide 13 and 14) I liked the bit of drama. If I had a blind student, I wonder how I would handle this. At the time, I really was more focused on getting the animations to appear correctly. I assumed that everyone was going to see them and like them. I wasn't aware of any reason not to include animations. Do I stop using animations on slides because one student in my class is blind? (S. Makwembere, personal communication, April 5, 2021)

Figure 7. Labour Law lecture slides with images

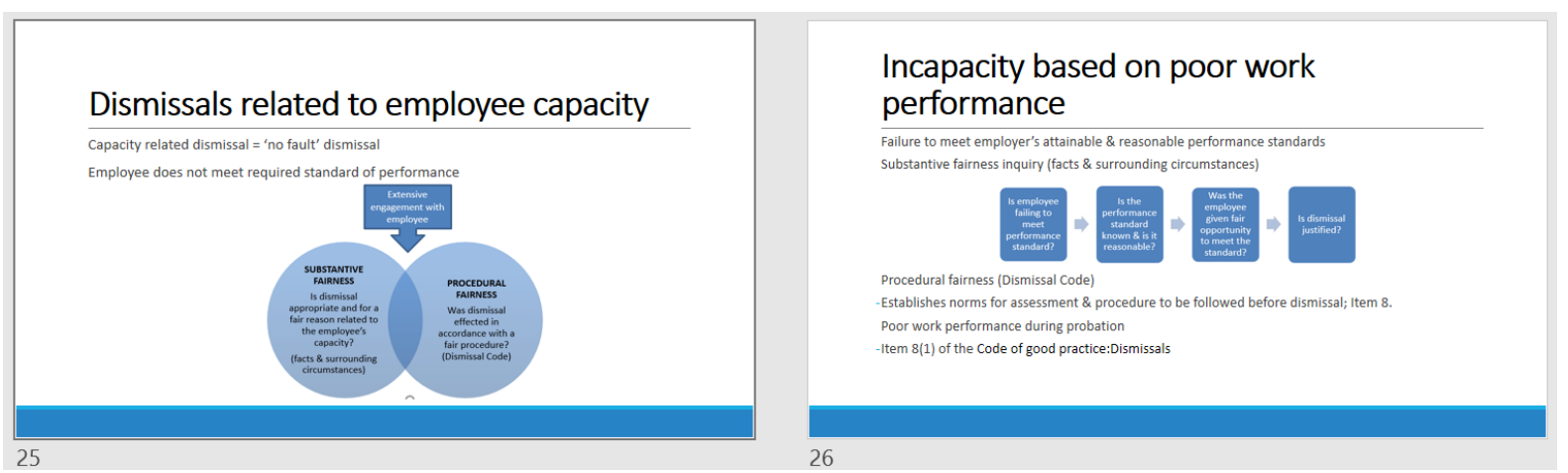

The images selected to be part of the lecture slides as well as the YouTube videos were my choice. During the lecture presentations, I would direct students' attention to particular points on slides and aspects of images or figures. I would use phrases such as 'As you can see here...' and 'What is clear here is...' when referring to certain content.

I also used prerecorded video content prepared using Screencast-o-matic, a video recording and editing software which I purchased at the price of USD\$19.80 for the year. When images were part of the lecture slides, I used the in-built pointer to refer to different parts of the images as illustrated in Figure 8.

Figure 8. Pointer use in Labour law prerecorded lecture video

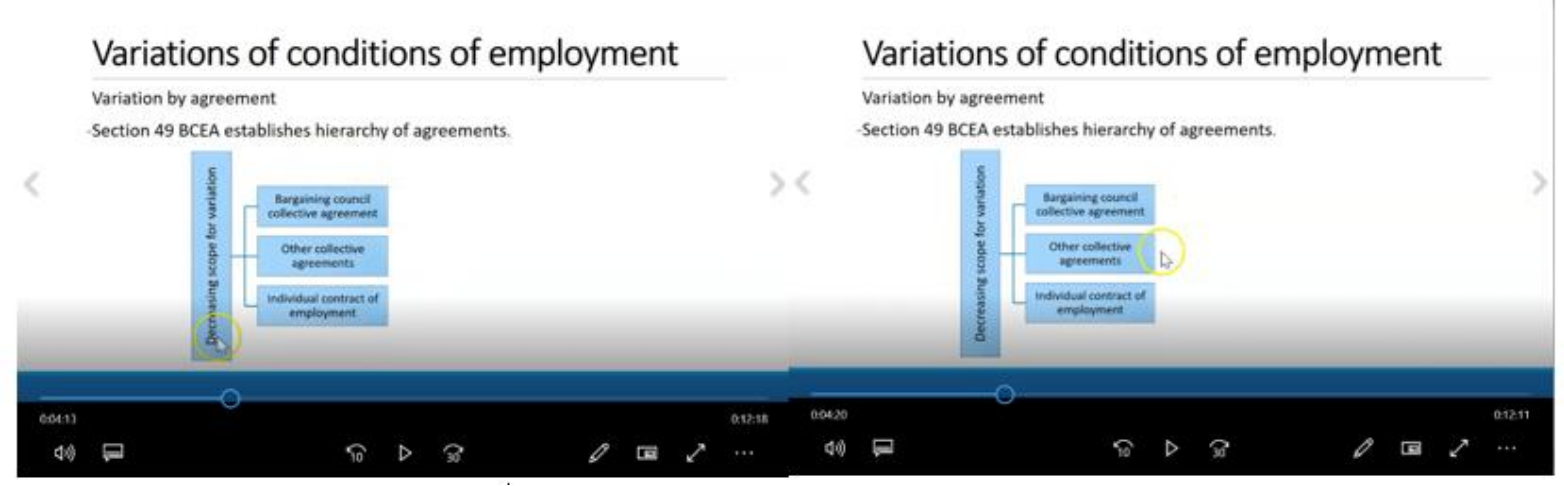


Makwembere, S. Disability Sensitivity and Sensibility: A Nondisabled Lecturer Perspective on Inclusive Lecturing Opportunities

Occasionally, YouTube videos would be part of pre-recorded content. The selection of these tended to be based on what I viewed as a video that gave useful information. Such videos included people presenting information such as in Figure 9 or only voice overs with images as illustrated in Figure 10.

Figure 9. Research methodology prerecorded lecture video with YouTube video

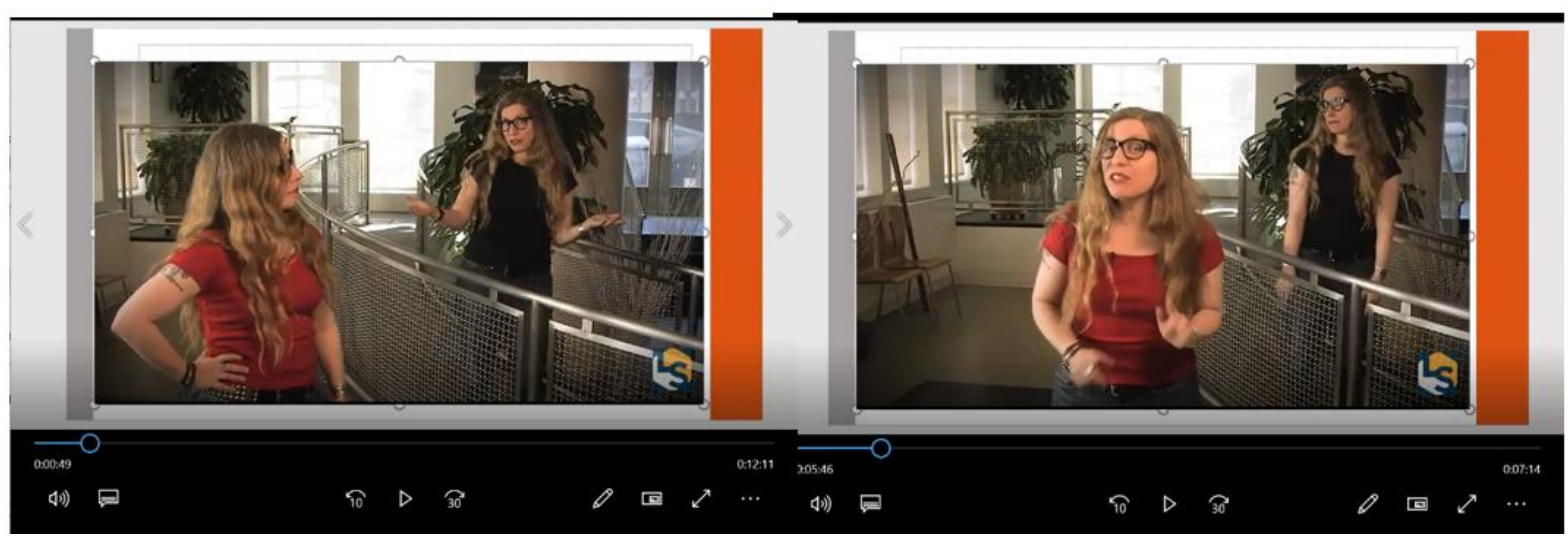

Figure 10. Business Management pre-recorded lecture video with YouTube video

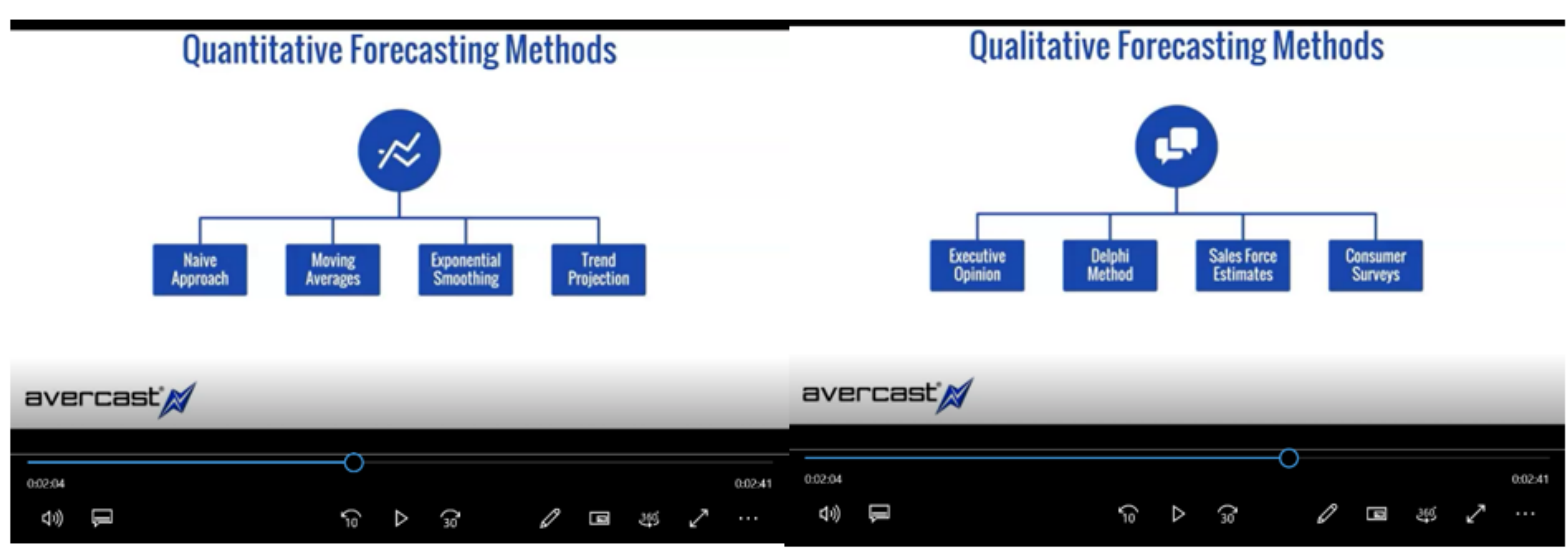

After rewatching the video in Figure 10, my reaction was as follows: "I can't believe there is so little text. I liked how the video simplified the techniques but wow, this was for a hearing and seeing audience. I prepared this for someone like me" (S. Makwembere, personal communication, April 8, 2021)

Also, I used pre-recorded videos to demonstrate various things such as how to create charts as shown in Figure 11. 
Makwembere, S. Disability Sensitivity and Sensibility: A Nondisabled Lecturer Perspective on Inclusive Lecturing Opportunities

Figure 11. Research methodology video to demonstrate how to create charts

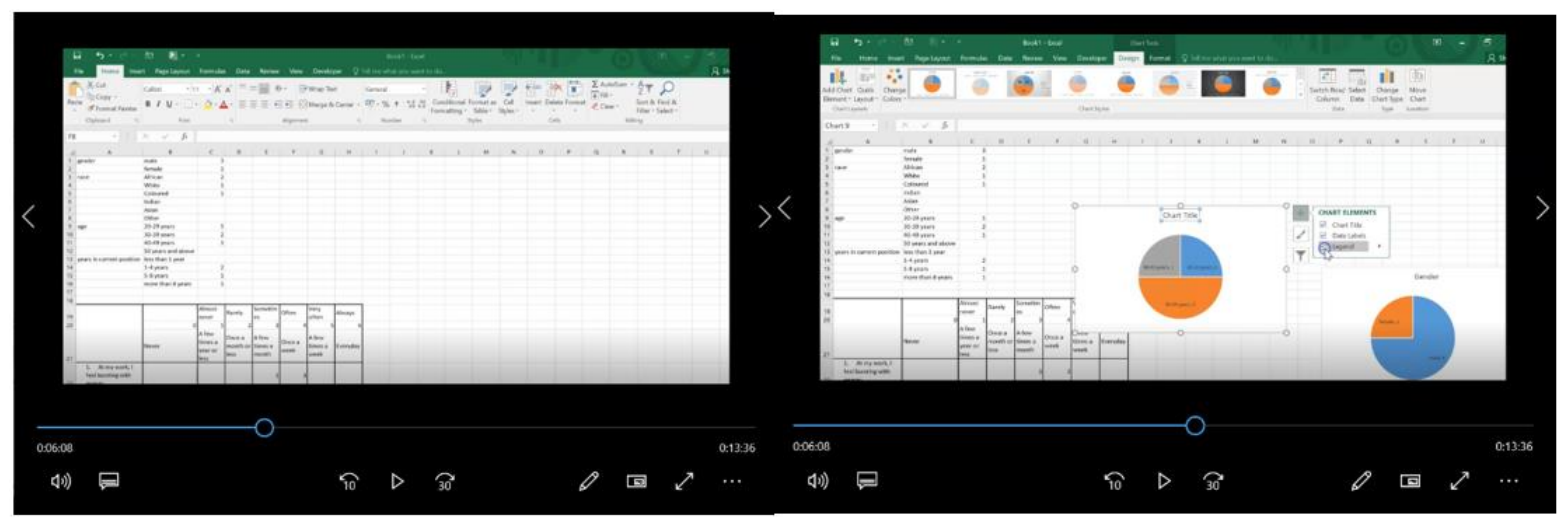

Pre-recorded videos were sometimes used to provide feedback on assessments (Figure 12).

Figure 12. Prerecorded video providing feedback on a Business Management assessment

Topic: Quality Management

Individual Assignment 1 - Due date: 28 October 2020

This assignment has 3 main parts. All 3 parts must be addressed in the assignment.

- Select examples of two (2) goods produced and two (2) services offered by businesses in South Africa.

i) Explain the need for quality in the businesses producing the goods and offering the services.

ii) Provide a detailed discussion of five (5) quality dimensions for each good and service. Include illustrations (e.g. pictures from adverts/customer reviews) as supporting evidence of the dimensions to demonstrate your understanding of the dimensions.

iii) From your selection of goods and services, choice 1 good and 1 service and find a story about the good or service that points to poor quality control. Attach the story to your assignment. Based on this story, discuss the forms of quality contiol that coulud have been implemented by the business to avoid the situation identified in the story you selected.

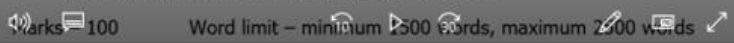

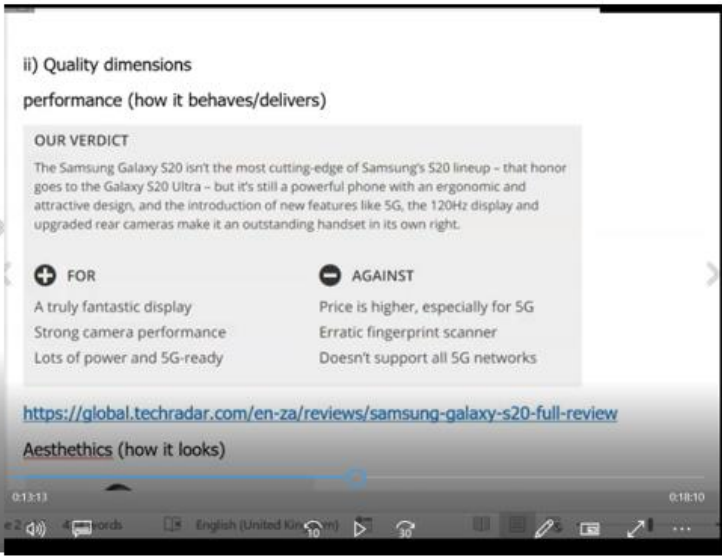

As with lecture presentations, in the pre-recorded videos, I would direct students' attention to certain points on slides and aspects of images or figures.

\section{Reinforcing disability silences}

Concerning references to disability, disability was referred to in a written form during three instances, two during the Research Methodology lectures and one during a Labour Law lecture. There were no extended discussions of disability in the classes associated with the slides. In the first instance, during a Research Methodology lecture, disability was referred to as part of examples of publication titles (Figure 13). The title was 'Career advancement challenges facing people with disabilities'. 
Makwembere, S. Disability Sensitivity and Sensibility: A Nondisabled Lecturer Perspective on Inclusive Lecturing Opportunities

Figure 13. Research Methodology lecture slides

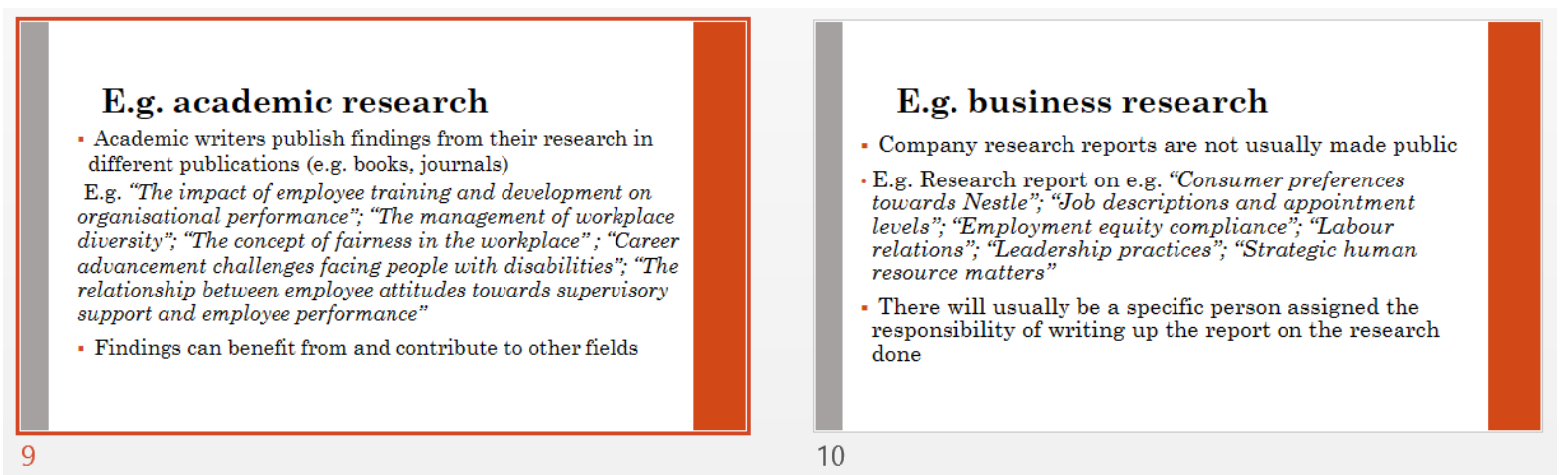

On the second occasion, during another Research Methodology lecture on research ethics, the Willowbrook study 'on children diagnosed with mental retardation' was cited (Figure 14).

Figure 14. Research Methodology lecture slides

\section{iv) Deception}

- Deception happens when researchers present their research as something other than what it is (withholding information/misleading participants)

- Some degree of deception appears common as researchers tend to want to limit participant's get more natural responses/avoid bias in th respondent's behaviour)

- Participants should be given an opportunity to know e.g. that they will be recorded

- Deceptive research cannot receive full informed consent

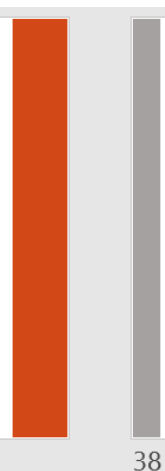

38

\section{Ethical dilemmas - e.g.s}

- During the Willowbrook study on children diagnosed with mental retardation (1963. 1966), these children were deliberately infected with the hepatitis virus. The children were fed bits of stools from infected people and later more purified virus was injected

- Consider this example. What might be a major ethical concern with such a study?

In the final instance, disability was referred to during a Labour Law lecture on the Employment Equity Act. People with disabilities were identified as belonging to the definition of designation groups.

Figure 15. Labour Law lecture slides

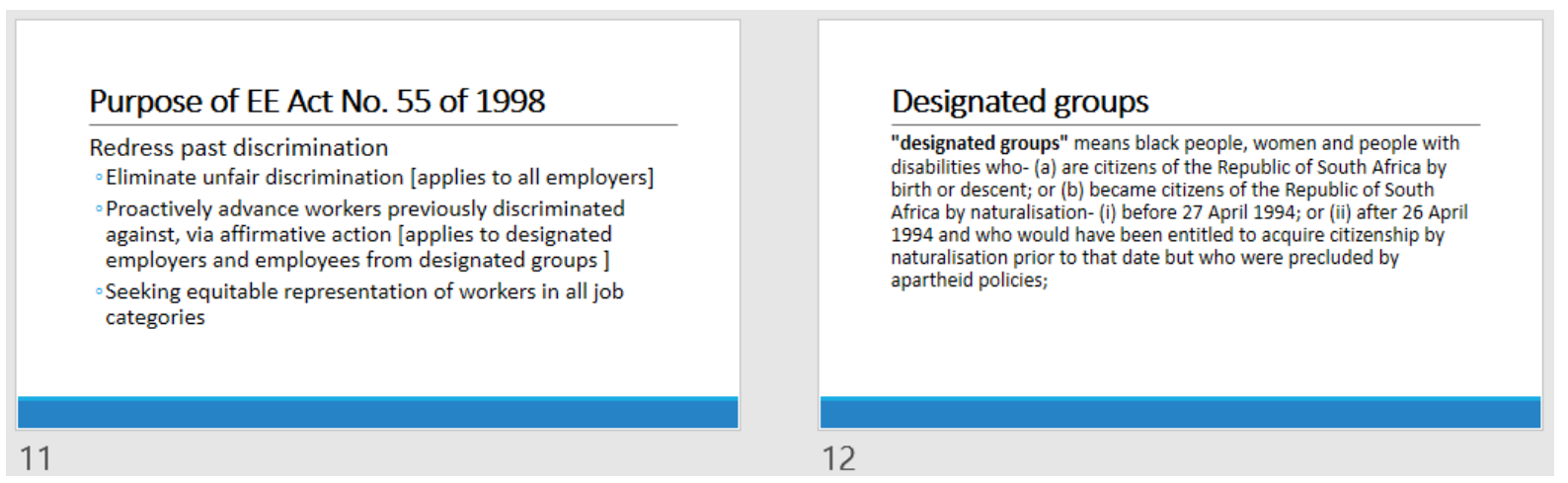


Makwembere, S. Disability Sensitivity and Sensibility: A Nondisabled Lecturer Perspective on Inclusive Lecturing Opportunities

No discussions on disability took place beyond these references made during these lectures. For the Willowbrook study in Figure14, I did not consider whether the slides reinforced any negative attitudes or beliefs about disability. My thoughts at the time were that the slide created a basis for discussion on unethical research.

My views on the way I handled the lecture with the Willowbrook study were that:

I saw mental retardation being referred to in different descriptions about the study and thought this was correct. This means the situation was not just my problem. The problem was that I just gave information without casting a critical eye over it. But, I didn't even know how to engage critically from a disability perspective...If it was not for these reflections, I was probably going to carry on referring to the term mental retardation...I needed help to know how to handle disability discussions in class. (S. Makwembere, personal communication, April 8, 2021)

I felt ill prepared to handle discussions relating to disability in class.

\section{Discussion}

Ableism characterised the patterns of perceptions of and assumptions about what was expected and the course material delivery. The form and formats of materials developed were taken to be "normal" and the delivery of information was perceived as "normal" albeit the "abnormal" circumstances of COVID-19. Accessibility for students with disabilities was not prioritised at the time. Mbuvha's (2019) study pointed to this lack of support from lecturers as well. YouTube videos and prerecorded videos had no additional features such as captions, subtitles or video transcripts. No steps were taken to check and make use of the Blackboard or Screencast-o-matic accessibility features. The choices were based on what was perceived as a 'normal' audience with similar learning needs in my academic reality. I met a "standard of normal" (Dolmage, 2017). This 'normal' category is socially invented and part of an "ableist 'reality' that...has been created, and is maintained, through higher education" (Dolmage, 2017, p. 6). My lecturing was ableist, for "able-bodiedness...represented as at once ideal, normal, and the mean or default" (Dolmage, 2017, p. 7). There was no sensitivity to the fact that the preparation and presentation of materials as well as the assumptions made valued ablebodiedness and inadvertently justified barriers of inequality for students with disabilities (Dolmage, 2017).

The absence of lecturing practices which took students with disabilities into account were similar to what students shared as their experiences in Mbuvha's (2019) study. Lecture planning and delivery processes under the ERTL circumstances took place without interrogating whether they were disability inclusive. This exemplified a lack of lecturer preparedness and ignorance concerning disability, also found amongst lecturers by Mutanga and Walker (2017). Students in Mbuvha's (2019) study expressed inaccessibility of learning due to a lack of such accommodations by lecturers. The failure to apply UDL principles meant that barriers to potential learning were present. These ableist practices of not applying UDL principles seemed to be dysconscious (Broderick \& Lalvani, 2017). Irrespective of no known students with disabilities, they created barriers, the kind of "barriers that have kept people with disabilities out of social institutions like universities" (Dolmage, 2017, p. 59). The justifications for producing the materials the way they were produced at the time were exclusionary and the 
Makwembere, S. Disability Sensitivity and Sensibility: A Nondisabled Lecturer Perspective on Inclusive Lecturing Opportunities

assumptions about the audience were exclusionary. The evidence points to little recognition or critical questioning of how lecturing accommodated diverse needs. This might not have been intentional. It highlights that indeed disability is a powerful invisible social force, which can lead to a conditioning, which finds the exclusion of students with disabilities as acceptable. From a human rights perspective, such lecturing practices do not create situations to facilitate selfdetermination, that is, they do not recognise the right of students with disabilities to take and develop responsibility for their learning decisions and situations (Donnelly, 2011).

The lecturing practices silenced disability experiences as they overlooked disability. This discounting of people with disabilities was also found by Gabel and Miskovic (2014), Rocco (2005) and Hirschmann (2014). Yoshida and Shanouda (2015) found, that experiences of people with disabilities are often silenced. Lectures neither included examples of disabilityrelated issues or images of people with disabilities nor facilitated a meaningful discussion on disability. The slide on the Willowbrook study exemplified how violently society has treated people with disabilities and the lecturing non-response exemplified how normalised this seemed to be. Society is accustomed to overlooking people with disabilities and their experiences (Rocco, 2005; Hirschmann, 2014). The use of the term mentally retarded is rejected. Referring to someone as mentally retarded is disrespectful and offensive (Granello, 2019; Garcia, Granello \& Boehm, 2020). Intellectual disability is the term considered more appropriate as it speaks to how society limits the individual as opposed to attributing fault to the individual (Cluley, 2018; VanDetta-Smitherman, 2018). Where disability related references are used in lectures without interrogation, as the evidence revealed, disability discourse is silenced (Gabel \& Miskovic, 2014). The importance of disability experiences, for example, through incorporating critical disability literature in curricula, is important.

\section{Conclusion}

There is no standardised disability support in South African higher education, therefore, many lecturers in HDIs can find themselves without guided support to address disability in their classrooms whether or not they have students with disabilities. Given this reality, lecturers still have their own agency and ability to self-correct. Inclusive higher education needs reflexivity that results in behavioural changes, which promotes truly inclusive teaching and learning practices. This article revealed some exclusionary lecturing practices adopted under ERTL during 2020. Neither lecturers nor their HEls are immune to society's dominant ableist discourse. While it is ideal for institutional support to be provided to lecturers to better handle disability, lecturers do not have to wait for their institutions to provide them with guidance on how to better support students with disabilities. Progressively inclusive changes can be made independent of institutional direction based on the rights accorded to people with disabilities. Lecturers do not have to wait to encounter students with disabilities. Through engaging in reflexive processes, an individual's agency can be activated to counter the marginalisation of students with disabilities and other forms of exclusionary higher education practices.

\section{Recommendations}

Studies on disability in higher education should be "about challenge, debate, uncertainty and new forms of academic production" (Swartz \& Watermeyer, 2006, p. 6). HEls (both public and private) should look to engage in disability research to enhance understanding and shift 
Makwembere, S. Disability Sensitivity and Sensibility: A Nondisabled Lecturer Perspective on Inclusive Lecturing Opportunities

practices both internally and in the higher education sector, through provoking critical thinking on disability because access to higher education is a social and human rights issue. Indicators of access to higher education should use holistic approaches. Enrolment into universities of students with disabilities should be deemphasised as a primary marker of access as this does not fully respond to the physical, social and legal barriers which impact the lived experiences of people with disabilities (Shakespeare, 2011). Disability assessments can rather focus on ways to broadly interrogate inclusivity. For example, instead of only establishing whether lecture theatres have ramps, measures can be introduced to evaluate the preparedness of lecturers to handle the delivery of courses to students with diverse learning needs in those lecture theatres or on online platforms.

Lecturers should intentionally and proactively devise and use tools to create the best learning environment for students (Appert et al., 2018; Kachani, Ross \& Irvin, 2020). These need not be completely new. Inclusive teaching principles can be followed such as establishing and supporting class settings that foster belonging to all students, establish clear student expectations, choose course content that appreciates diversity and recognises barriers to inclusion, design every course element for accessibility and reflect on teaching beliefs to increase self-awareness and one's commitment to inclusion (Appert et al., 2018; Kachani et al., 2020). When preparing lecture content in a variety of forms (for example, Powerpoint presentations and videos), use different ways of representing and supporting materials (for example, illustrations, summaries, captions and alternative text for images), choose course content by authors of diverse backgrounds and that reflects systematically underrepresented or missing perspectives and plan for the use multiple methods to convey information and adjustable formats (Appert et al., 2018; Gillian-Daniel et al., 2020). In the classroom, establish guidelines to promote inclusive learning in the classroom with students, build rapport with students through, for example, learning their names, having online chats and sharing about your interests, diversify class activities to offer a variety of ways for students to participate in class, use examples that reflect diversity and intersectionality, extend ways of encouraging class engagement, for example, designing activities or assignments with students, build awareness of student behaviours in the classroom and devise ways to deal with challenging behaviours such as microaggression and address, not ignore, difficult classroom behaviours such as offensive comments, by extending opportunities to probe the behaviours without attributing motive as well as applying existing policies and procedures and direct students to where they can get additional support (Appert et al., 2018; Schuelka et al., 2019; Kabel et al, 2021; Kachani et al., 2021). Concerning teaching beliefs, avoid making assumptions about students' abilities, treat every student as an individual, consider individual positionality and interrogate the ways perceptions of the self and others have been shaped, probe conscious and unconscious biases (Appert et al., 2018; Schuelka et al., 2019; Gillian-Daniel et al., 2020; Kachani et al., 2021; Naraian, 2021).

It will not be possible for HDls to achieve all that would be necessary to ensure lecturers, as key role players of inclusive higher education, immediately have the resources and knowledge they need to address disability issues. Therefore, strategies to progressively build capacities should be developed with staff and students with disabilities and as far as possible, include other key role players in the disability community to ensure that needs are appropriately met. These 
Makwembere, S. Disability Sensitivity and Sensibility: A Nondisabled Lecturer Perspective on Inclusive Lecturing Opportunities

strategies can include identifying and establishing relationships with key stakeholders who can meaningfully participate in the dialogue on inclusive reform, providing diversity and inclusion workshops and reviewing policies for inclusivity and making changes where there are weaknesses (Appert et al., 2018; Kachani et al., 2020). As the strategies are implemented, lecturers should be encouraged to reflect on the ways they are implementing these and share them. The presence of a safe environment will be vital for this, therefore, careful consideration should be given to how the revelations will be handled if they are used for performance management.

\section{References}

Adams, T. E., Jones, S. H., \& Ellis, C. (2015). Autoethnographic research design and philosophy. Autoethnography (Understanding Qualitative Research), 1-20. https://doi.org/ 10.1177/160940690600500205

Africa, C., \& Mutizwa-Mangiza, S. (2018). The need for a new language? How historically disadvantaged institutions grapple with the effects of labelling in Higher Education: the case of the University of the Western Cape. Politikon, 45(1), 81-93. https://doi.org/10.1080/02589346.2018.1418213

Appert, L., Jungels, A., Bean, C., Klaf, S., Irvin, A., \& Phillipson, M. (2018). Guide for inclusive teaching at Columbia. Columbia Centre for Teaching and Learning. University of British Columbia.

Broderick, A., \& Lalvani, P. (2017). Dysconscious ableism: toward a liberatory praxis in teacher education. International Journal of Inclusive Education, 21(9), 894-905. https://doi.org/10.1080/13603116.2017.1296034

Broido, E. M. (2020). Making Disability Research Useful (Practice Brief). Journal of Postsecondary Education and Disability, 33(3), 275-281.

Brown, S., \& Race, P. (2003). Lecturing: A practical guide. Routledge.

Chiwandire, D. (2019). Universal Design for Learning and Disability Inclusion in South African Higher Education Curriculum. Alternation Special Edition, 27, 6-36.

Cluley, V. (2018). From "Learning disability to intellectual disability" - Perceptions of the increasing use of the term "intellectual disability" in learning disability policy, research and practice. British Journal of Learning Disabilities, 46(1), 24-32.

https://doi.org/10.1111/bld.12209

Croft, A. (2010). Including disabled children in learning: Challenges in developing countries. Brighton, UK: Consortium for Research on Educational Access, Transitions and Equity.

D'Souza, R. (2020). Exploring ableism in Indian schooling through the social model of disability. Disability \& Society, 35(7), 1177-1182. https://doi.org/10.1080/09687599. $\underline{2019.1668635}$

Dallas, B. K., Sprong, M. E., \& Kluesner, B. K. (2016). Multiuniversity Comparison of Faculty Attitudes and Use of Universal Design Instructional Techniques. Rehabilitation Research, Policy, and Education, 30(2), 148-160. https://doi.org/10.1891/21686653.30.2.148

Donnelly, V. (Ed.). (2011). Key principles for promoting quality in inclusive education: Recommendations for practice. European Agency for Development in Special Needs Education. 
Makwembere, S. Disability Sensitivity and Sensibility: A Nondisabled Lecturer Perspective on Inclusive Lecturing Opportunities

Dreyer, L., Mostert, Y., \& Gow, M. A. (2020). The promise of equal education not kept : specific learning disabilities - the invisible disability. African Journal of Disability, 9(1), 1-10. https://doi.org/10.4102/ajod.v9i0.647

Drisko, J. W., \& Maschi, T. (2016). Content analysis. Pocket Guides to Social Work R.

Fiske, J. (1990). Ethnosemiotics: Some personal and theoretical reflections. Cultural Studies, 4(1), 85-99. https://doi.org/10.1080/09502389000490061

Gabel, S. L., \& Miskovic, M. (2014). Discourse and the containment of disability in higher education: an institutional analysis. Disability \& Society, 29(7), 1145-1158.

Garcia, G. L., Granello, D. H., \& Boehm, K. D. (2020). At Last-Empirical Proof That the "RWord" Really Must Go: The Influence of Terminology on Tolerance. Inclusion, 8(2), 155-162.

Gillian-Daniel, D. L., Petty, E. M., Schmid, M. E., Stahr, A., \& Raymond, N. C. (2020). Addressing Biases in Health Care by Promoting Inclusive Teaching Practices Among Faculty in Health Professions Education Programs: "Learning to Say the Right Words at the Right Time." New Directions for Teaching and Learning, 2020(162), 123-133. https://doi.org/ 10.1002/tl.20397

Granello, D. H. (2019). The R-Word Is More Than Hate Speech: Differences in Counselors' Level of Tolerance Based on Language and Labels. The Journal of Humanistic Counseling, 58(3), 170-183. https://doi.org/10.1002/johc.12118

Griful-Freixenet, J., Struyven, K., \& Vantieghem, W. (2021). Toward More Inclusive Education: An Empirical Test of the Universal Design for Learning Conceptual Model Among Preservice Teachers. Journal of Teacher Education, 72(3), 381-395. https://doi.org/10.1177/0022487120965525

Hirschmann, N. J. (2014). 10. Invisible Disability: Seeing, Being, Power. In Civil Disabilities (pp. 204-222). University of Pennsylvania Press.

Hosking, D. L. (2008, September 2-4). Critical disability theory. In A paper presented at the 4th Biennial Disability Studies Conference at Lancaster University, UK (Vol. 14, No. 5, p. 736).

Howell, C. (2018). Participation of students with disabilities in South African higher education: Contesting the uncontested. Education and disability in the Global South: New perspectives from Africa and Asia, 127-143.

Hsu, T.-H., Chao, P.-J., Kuo, C.-N., Huang, Y.-T., \& Fried, J. H. (2020). Exploring the practices of inclusive instruction and perceptions toward disability among vietnamese university faculty members. The Journal of Rehabilitation, 86(1), 41-53

Kabel, M., Hwang, J., \& Hwang, J. (2021). Lessons Learned From a Rural Classroom Study: Transitioning From Concrete to Virtual Manipulatives to Teach Math Fact Fluency to Students With Learning Disabilities. Journal Of Curriculum Studies Research, 3(1), 4268. https://doi.org/10.46303/jcsr.2021.7

Kachani, S., Ross, C., \& Irvin, A. (2020). 5 Principles as Pathways to Inclusive Teaching. Inside Higher Ed. https://www.insidehighered.com/advice/2020/02/19/practical-stepstoward-more-inclusive-teaching-opinion

Kilinc, S. (2021). Mothers of children without disabilities' conceptions of inclusive education: unveiling an exclusionary education system privileging normality and ableism. Disability \& Society, 1-25. 
Makwembere, S. Disability Sensitivity and Sensibility: A Nondisabled Lecturer Perspective on Inclusive Lecturing Opportunities

Lawson, A., \& Beckett, A. E. (2020). The social and human rights models of disability: towards a complementarity thesis. The International Journal of Human Rights, 25(2), 1-32. https:// doi.org/10.1080/13642987.2020.1783533

Lyner-Cleophas, M. M. (2016). Staff and disabled students' experiences of disability support, inclusion and exclusion at Stellenbosch University (Doctoral dissertation, Stellenbosch: Stellenbosch University).

Mayring, P. (2000). Qualitative content analysis, forum. Qualitative social research, 1(2), 4356.

Mbuvha, T. (2019). Kinds of Support Offered by the Disability Unit to Students with Disabilities at Institutions of Higher Learning in South Africa: A Case Study of the University of Venda. Journal of Student Affairs in Africa, 7(2), 57-73. https://doi.org/10.24085/jsaa.v7i2.3825

McGeehan, D. A. (2020). An Investigation of Postsecondary Centers for Teaching Excellence Support for Universal Design for Learning (Doctoral dissertation, Duquesne University).

Mitra, S., \& Sambamoorthi, U. (2014). Disability prevalence among adults: estimates for 54 countries and progress toward a global estimate. Disability and rehabilitationRehabilitation, 36(11), 940-947. https://doi.org/10.3109/09638288.2013.825333

Morley, L. (2011). African higher education: researching absences, equalities and aspirations. Research in Comparative and International Education, 6 (4), 341-347. https://doi.org/ 10.2304/rcie.2011.6.4.341

Morley, L., \& Croft, A. (2011). Agency and advocacy: Disabled students in higher education in Ghana and Tanzania. Research in Comparative and International Education, 6(4), 383399. https://doi.org/10.2304/rcie.2011.6.4.383

Moswela, E., \& Mukhopadhyay, S. (2018). Double jeopardy: Plight of female students with disabilities in Botswana's higher education. Indian Journal of Gender Studies, 25(3), 384-409. https://doi.org/10.1177/0971521518785721

Munemo, E., \& Bekele, Y. (2020). Inclusion of Students with Visual Impairment in Higher Education: Experiences from Ethiopia and Zimbabwe. In Inclusion as Social Justice (pp. 218-240). Brill Sense.

Mutanga, O. (2017). Students with disabilities' experience in South African higher educationa synthesis of literature. South African Journal of Higher Education, 31(1), 135-

154. https:// doi.org/10.20853/31-1-1596

Mutanga, O. (2018). Inclusion of Students with Disabilities in South African Higher Education. International Journal of Disability, Development, and Education, 65(2), 229-242. https://doi.org/10.1080/1034912X.2017.1368460

Mutanga, O., \& Walker, M. (2017). Exploration of the academic lives of students with disabilities at South African universities: Lecturers' perspectives. African Journal of Disability, 6(1), 1-9. https://doi.org/10.4102/ajod.v6i0.316

Naraian, S. (2021). Making inclusion matter: critical disability studies and teacher education. Journal of Curriculum Studies, 53(3), 298-313. https://doi.org/10.1080/ $\underline{00220272.2021 .1882579}$ 
Makwembere, S. Disability Sensitivity and Sensibility: A Nondisabled Lecturer Perspective on Inclusive Lecturing Opportunities

Ngubane-Mokiwa, S. A., \& Zongozz, J. N. (2021). Exclusion Reloaded: The Chronicles of Covid19 on Students with Disabilities in a South African Open Distance Learning Context. Journal of Intellectual Disability-Diagnosis and Treatment, 9(1), 137-147. https:// doi.org/10.6000/2292-2598.2021.09.01.17

Nurjannah, A. P. L., Rahajeng, U. W., \& Arawindha, U. (2021, June). Disability is Diversity: A Multiculturalism Perspectives on Disability Inclusion in Higher Education. In ISCS 2020: Proceedings of the 1st International Seminar on Cultural Sciences, ISCS 2020, 4 November 2020, Malang, Indonesia (p. 266). European Alliance for Innovation.

Oliver, M. (1983). Introduction: setting the scene. In Social Work with Disabled People (pp. 15). Palgrave, London.

Oliver, M. (1990). The politics of disablement. London: Macmillan Education Ltd.

Osborne, T. (2019). Not lazy, not faking: teaching and learning experiences of university students with disabilities. Disability \& Society, 34(2), 228-252. https://doi.org/10.1080/09687599.2018.1515724

Pedroza, T. (2019). Pause with a Cause. IN THE POCKETS OF YESTERDAY'S PANTS, 26.

Pillay, D., Naicker, I., \& Pithouse-Morgan, K. (Eds.). (2016). Academic autoethnographies: Inside teaching in higher education. Springer.

Pudaruth, S., Gunputh, R. P., \& Singh, U. G. (2017). Forgotten, excluded or included? Students with disabilities: A case study at the University of Mauritius. African Journal of Disability, 6, 1-12. https://10.4102/ajod.v6i0.359

Quinn, G., \& Degener, T. (2002). The moral authority for change: human rights values and the worldwide process of disability reform. Human Rights and Disability: The current use and future potential of United Nations human rights instruments in the context of disability. New York, Geneva: United Nations, 9-18.

Rocco, T. (2005). The invisible people: Disability, diversity, and issues of power in adult education. Presented at the Midwest Research-to-Practice Conference in Adult, Continuing, and Community Education, Northern Illinois University, DeKalb, IL, October 9-11, 2002

Rueda, M. M., \& Cerero, J. F. (2019). Main barriers to ICT teacher training and disability. Research in Social Sciences and Technology, 4(2), 96-114.

Samaha, A. M. (2007). What good is the social model of disability? The University of Chicago Law Review, 74(4), 1251-1308. https://doi.org/10.1080/09687599.2017.1300390

Schuelka, M. J., Johnstone, C. J., Thomas, G., \& Artiles, A. J. (Eds.). (2019). The Sage handbook of inclusion and diversity in education. SAGE.

Shakespeare, T. (2011). The social model of disability. In L. J. Davis (Ed.), The disability studies reader (pp. 214-221). Routledge.

Snounu, Y. (2019). Disability and Higher Education in Palestine. Journal of Culture and Values in Education, 2(3), 61-78. https://doi.org/10.46303/jcve.03.02.4

Starr, L. J. (2010). The use of autoethnography in educational research: Locating who we are in what we do. Canadian Journal for New Scholars in Education/Revue canadienne des jeunes chercheures et chercheurs en éducation, 3(1),

Svendby, R. (2020). Lecturers' Teaching Experiences with Invisibly Disabled Students in Higher Education: Connecting and Aiming at Inclusion. Scandinavian Journal of Disability Research, 22(1), 275-284. https://doi.org/10.16993/sjdr.712 
Makwembere, S. Disability Sensitivity and Sensibility: A Nondisabled Lecturer Perspective on Inclusive Lecturing Opportunities

Swartz, L., \& Watermeyer, B. Introduction and overview. Watermeyer, B., Swartz, L., Lorenzo, T., Priestley, M., \& Schneider, M. (Eds.). (2006). Disability and social change: A South African agenda. HSRC Press., 1-7.

Swartz, L., Hunt, X., Watermeyer, B., Carew, M., Braathen, S. H., \& Rohleder, P. (2018). Symbolic violence and the invisibility of disability. African Safety Promotion: A Journal of Injury and Violence Prevention, 16(2), 21-30.

Thomas, C. (1999). Female Forms: Experiencing and Understanding Disability. Open University Press.

Timberlake, M. (2020). Recognising ableism in educational initiatives: Reading between the lines. Research in Educational Policy and Management, 2(1), 84-100.

VanDetta-Smitherman, C.A. (2018). Elimination of the Invisible Barriers to Social Inclusion: Dissecting the Role of Terminology in Services and Supports Related to Intellectual Disability (Doctoral dissertation, Creighton University).

Verstraete, P. (2017). Silence or the sound of limpid water: Disability, power, and the educationalisation of silence. Paedagogica Historica, 53(5), 498-513. https://doi.org/10.10 80/00309230.2017.1296475

Yoshida, K. K., \& Shanouda, F. (2015). A culture of silence: modes of objectification and the silencing of disabled bodies. Disability \& Society, 30(3), 432-444. https://doi.org/10.1080/09687599.2015.1019042

Zongozzi, J. N. (2020). Accessible quality higher education for students with disabilities in a South African open distance and e-learning institution: Challenges. International Journal of Disability, Development and Education, 1-13. https://doi.org/10.1080/ $1034912 X .2020 .1822518$

Zongozzi, N., Sefora, S. R., Mokiwa, S. N., \& Agejivwie, S. R. S. N. (2019). Opening up education through academic support for Students with Disabilities. Pan Commonwealth Forum. 